http://dx.doi.org/10.18778/8088-220-1.12

\author{
Jarosław Płuciennik \\ Jagoda Sałaj \\ Uniwersytet Łódzki \\ Katedra Teorii Literatury, Instytut Kultury Współczesnej
}

\title{
STYLE PISANIA W SFERZE PUBLICZNEJ WSPÓŁCZESNE DZIENNIKARSTWO WEDEUG UMBERTA ECO NA TLE ANTYCZNEJ REFLEKSJI O POEZJI
}

\section{Streszczenie}

Przedmiotem zainteresowań jest relacja pomiędzy literaturą, dziennikarstwem oraz sferą publiczną i sferą prywatną. Aby dookreślić relacje, sięgamy do współczesnych koncepcji badawczych (Habermas, Eco, Pinker, Lippmann), konfrontując je z antyczną refleksją literaturoznawczą Horacego. Omawiając kolejne okresy ewolucji dziedziny dziennikarstwa, skupiamy się przede wszystkim na przeobrażeniach stylów pisania w sferze publicznej. W kontekście literatury staramy się usytuować nowe style i rodzaje dziennikarstwa (gonzo journalism, citizen journalism, literary journalism). Prezentując specyfikę funkcjonowania dzisiejszej prasy, nakreślamy obraz profesji dziennikarskiej, krytycznie komentując przy tym jakość współczesnych przekazów informacyjnych.

Słowa kluczowe: style pisania, dziennikarstwo, jakość, sfera publiczna

\footnotetext{
Summary

Styles of writing in the public sphere. Modern journalism according to Umberto Eco in comparison with ancient reflections regarding poetry

The aim of the article is to describe the relationship between literature, journalism, the public sphere and the private sphere. At first, the paper presents the current concepts of research in the mentioned categories (Habermas, Eco, Pinker, Lippmann) and next confronts them with the ancient Horace's literary reflection. Discussing the evolution of journalism, (especially newspapers industry) and worldwide mass communication we focus primarily on writing styles developing in different periods of time in the public sphere. This piece is an attempt to situate new styles of writing and types of journalism (gonzo journalism, citizen journalism, literary journalism) in the context of literature. Presenting an overview of the contemporary press with critical comment on its quality, we outline the image of the profession of journalism and what is essential for a good media system.
}

Keywords: styles of writing, journalism, quality, the public sphere 
Żeby wiedzieć, co ma być $\mathrm{w}$ gazecie, trzeba, jak mawiają w redakcjach, określić porządek dnia. Wiadomości do zakomunikowania jest na świecie bez liku, ale dlaczego mamy podawać, że był wypadek w Bergamo, a nie podawać, że był inny wypadek w Mesynie? To nie wiadomości czynią gazetę, to gazeta czyni wiadomości. Składając umiejętnie cztery różne wiadomości, proponuje się czytelnikowi wiadomość piątą ${ }^{38}$.

Powyższy fragment pochodzi z najnowszej powieści Umberta Eco pt. Temat na pierwsza stronę (2015), stanowiąc intrygujący punkt wyjścia do rozważań nad współczesnym ładem medialnym. Przedstawia bowiem specyfikę funkcjonowania współczesnej prasy, a także opisuje ważny mechanizm charakteryzujący nowe media - mowa tutaj o „agenda setting”, procesie wyboru zdarzeń medialnych i silnym koncentrowaniu opinii publicznej. Według specjalistów z obszaru nauk o komunikowaniu „agenda setting” stanowi jedną z podstawowych funkcji dziennikarstwa: media kierują uwagę swoich odbiorców na konkretne wyselekcjonowane przez siebie materiały, nadając im odpowiednią hierarchię ważności. Każda informacja, zanim zostanie zaprezentowana szerokiemu gronu odbiorców, jest poddawana szeregowi dyskusji, wyborów i obróbek. Prasa stawia określone tematy w centrum zainteresowania, czyniąc z nich tytułowy „temat na pierwszą stronę”. Często dzieje się tak, że mimo ogromu bieżących zdarzeń, każdego dnia dominuje wyłącznie jedno, spychające bezpośrednio całą resztę na dalszy plan ${ }^{39}$. Jako pierwszy teorię agenda-setting opisał w latach dwudziestych XX wieku Walter Lippmann ${ }^{40}$, uważając, że „poprzez ogólny zbiór przekazywanych informacji media kształtują w naszych głowach obrazy" ${ }^{41}$. Jego spostrzeżenia rozwijali w latach sześćdziesiątych XX wieku Maxwell McCombs i Donald Shaw, udowodniając przeprowadzonymi przez siebie badaniami trafność zjawiska zaobserwowanego wcześniej przez amerykańskiego socjologa i publicystę Lippmanna. Badacze wprowadzili wówczas rozbudowany termin „agenda setting”, najpierw w artykule The Agenda-Setting Function of Mass Media (1972), a następnie w książce The Emergence of American Political Issues (1977), zauważając, że media wpływają w ogromnym stopniu na kształtowanie się opinii publicznej. Marek Chyliński, twórca Instytutu Dziennikarstwa Polskapresse i wieloletni dziennikarz, oraz Stephan Russ-Mohl z Uniwersytetu w Lugano (Szwajcaria) w swojej książce Dziennikarstwo, będącej pierwszą na polskim rynku wydawniczym aspirującą do bycia podręcznikiem nauki zawodu dziennikarskiego, podkreślają, że współcześnie ciekawość

38 U. Eco, Temat na pierwsza stronę, przeł. K. Żaboklicki, Warszawa 2015, s. 49.

39 M. Chyliński, S. Russ-Mohl, Dziennikarstwo, Warszawa 2008, s. 19.

40 W. Lippmann, Public Opinion, New York 1992.

${ }^{41}$ M. McCombs, Ustanawianie agendy: Media masowe $i$ opinia publiczna, przeł. B. Radwan, Kraków 2006, s. 6. 
badaczy wzbudza również „media agenda setting”. To stosunkowo młode pojęcie, oznaczające wytwarzanie ważności wydarzeń w świadomości ludzi związanych bezpośrednio z mediami (wydawców, reporterów, redaktorów). Można się zatem zastanawiać, jakimi motywami kierują się ludzie z branży medialnej decydujący się wyróżnić konkretne zdarzenia w danym dniu. Tym samym zjawisko selekcji informacji i przekazywania ich do opinii publicznej - obok samego procesu ewolucji zawodu dziennikarskiego, problemu konwergencji mediów, kategorii prawdy, literackości wypowiedzi dziennikarskich, organizacji pracy redaktorskiej, nowoczesnych trendów panujących w mediach, a także zmian związanych z rozszerzaniem się środowiska dziennikarskiego oraz samej przyszłości tego zawodu - staje się istotnym punktem rozważań medioznawczych, językoznawczych oraz kulturoznawczych.

Umberto Eco akcję swojej najnowszej powieści osadził w 1992 roku we Włoszech. Głównym bohaterem jest człowiek o nazwisku Colonna ${ }^{42}$, dziennikarz i ghost writer, który zostaje wynajęty do napisania książki dokumentującej powstawanie nowej gazety "Jutro". Czasopismo to ma zrewolucjonizować rynek prasowy, a w założeniu twórców jego głównym celem ma być wyprzedzanie innych dzienników o jeden dzień i informowanie o rzeczach, które dopiero się wydarzą. Autor wylicza prymarne cechy projektu:

Dlaczego "Jutro"? Dlatego, że gazety tradycyjne podawały i niestety podają nadal wiadomości z poprzedniego wieczoru [...]. Otóż wiadomości z poprzedniego wieczoru usłyszeliśmy w telewizji o dwudziestej, więc w dziennikach czytamy zawsze o rzeczach nam już znanych, stąd też gazet sprzedaje się coraz mniej. W „Jutrze" te śmierdzące już jak nieświeża ryba wiadomości trzeba będzie tylko streścić i przypomnieć, ale wystarczy na to jedna kolumienka, którą przeczyta się w kilka minut. [...] Przeznaczeniem dziennika jest obecnie upodobnienie się do tygodnika. Będziemy pisać o tym, co mogłoby się stać jutro, pogłębiać, uzupełniać dochodzenia, uprzedzać $w$ nieoczekiwany sposób... $[\ldots]^{43}$.

W trakcie lektury czytelnik dowiaduje się, że „Jutro" to jedynie mistyfikacja, a pierwszy egzemplarz tak naprawdę nigdy się nie ukaże. Prace nad „numerem zerowym” gazety (oryginalny tytuł powieści Numero zero) są swoistym zamieszaniem, mającym pomóc głównemu właścicielowi w wypromowaniu własnego wizerunku i zdobyciu odpowiednich kontaktów. Temat na pierwsza stronę

42 Colonna to stary ród włoski, który uwikłany był w wiele skandali, wojen i sporów z papieżami oraz rzymskimi rodzinami szlacheckimi. Colonna to także miejscowość i gmina we Włoszech. Słowo „colonna” w języku włoskim oznacza „kolumna”, co można odnieść do kolumny gazetowej w układzie strony: http://pl.pons.com/t\%C5\%82umaczenie? $\mathrm{q}=$ colonna\&l=itpl\&in=\&lf=it [dostęp: 20.11 .2015 ].

43 U. Eco, Temat na..., s. 29. 
to intrygujący utwór z elementami political fiction, thrillera i groteski, ponadto książkę wyróżnia charakterystyczne dla twórczości Eco ukryte przesłanie, sieć informacji, które należy odszyfrować, by w pełni zrozumieć sens powieści. Eco ${ }^{44}$ to włoski pisarz, filozof, semiolog oraz mediewista zajmujący się od kilkudziesięciu lat zagadnieniami procesów komunikacji masowej i estetyki. Przez długi czas był związany z mediolańskim tygodnikiem „L'Espresso”, w którym publikował swoje felietony, duża cześć tekstów drukowanych tam w latach osiemdziesiątych i dziewięćdziesiątych została w późniejszym czasie wydana w trzech autorskich zbiorach: Zapiski na pudetku od zapałek (1993), Drugie zapiski na pudetku od zapatek 1991-1993 (1994), Trzecie zapiski na pudetku od zapatek 1994-1996 (2005). Eco jako teoretyk, ale również praktyk w swoich licznych artykułach i rozprawach porusza tematykę wadliwego dziennikarstwa. Przez wiele lat miał okazję przypatrywać się oraz bezpośrednio uczestniczyć w zmianach zachodzących w świecie mediów, wiele alarmujących spraw zdecydował się przedstawić szerszej publiczności ${ }^{45}$.

Semiolog w Temacie na pierwszą stronę przedstawia niepokojącą wizję współczesnego świata kształtowanego przez środki masowego przekazu. Autor w fikcyjną powieść wplata spostrzeżenia pochodzące z własnych obserwacji, dotyczące kondycji dziennikarstwa, zawodu dziennikarza oraz etyki tej profesji ${ }^{46}$. Mediewista w sposób krytyczny opisuje jakość współczesnej informacji oraz pracy dziennikarskiej, a jego refleksje stają się przyczynkiem do podjęcia rozważań na temat obecnych tendencji piśmienniczych w dziennikarstwie. Filozof wprowadza charakterystyczne porównania do „nieświeżej ryby”, „jednej kolumienki” (w cytowanym powyżej fragmencie) - prezentujące uwarunkowania funkcjonowania prasy. Projekt gazety „Jutro” naszkicowany przez Eco z założenia polegał na stworzeniu czasopisma mającego przedstawiać nowy model dziennikarstwa, które jest niezależne od wszelkich zewnętrznych nacisków - czy to politycznych, czy społecznych. W powieści włoskiego pisarza przemówienie wolnym głosem okazuje się niemożliwe, a jak sytuacja wygląda poza światem powieści, czyli w rzeczywistości?

Dziennikarstwo stanowi dziś odmienną dyscyplinę akademicką i nie sposób nie docenić w nim solidnej wiedzy naukowej. Należy zaakcentować, że jest to również zawód wymagający nieustannego uczenia się, poprzez wykorzystywanie najnowszych technik zmusza uprawiających go ludzi do poszerzania

${ }^{44}$ Umberto Eco w maju 2015 roku został doktorem honoris causa Uniwersytetu Łódzkiego.

${ }^{45}$ Zob. Apokaliptycy i dostosowani: Komunikacja masowa a teorie kultury masowej (2010), Rakiem. Goraca wojna i populizm mediów (2007).

${ }_{46}$ Książka ma dodatkowo postać dziennika, co wprowadza element prawdziwości. Czytelnik może mieć wrażenie, że odczytuje notatki redaktora gazety. 
interdyscyplinarnej wiedzy oraz coraz większej profesjonalizacji ${ }^{47}$. Zależność tę widać w szybko wzrastającej liczbie publikacji poruszających praktyczny wymiar tego rzemiosła. W ostatnich latach można zaobserwować wzmożoną aktywność praktyków - dziennikarzy pracujących w zawodzie ${ }^{48}$ - pragnących podzielić się swoim doświadczeniem z ludźmi dopiero wchodzącymi na ścieżkę specjalistycznej kariery. Powstają liczne poradniki, podręczniki retoryczne i pisarskie, w których autorzy w jak najbardziej kompleksowy sposób starają się przekazać praktyczny obszar wiedzy ${ }^{49}$. Początkowo taka tendencja była widoczna głównie w Stanach Zjednoczonych oraz w innych krajach zachodnich, gdzie na potęgę wydawano pozycje poświęcone szlifowaniu sprawności językowej w mowie i piśmie, czyli kreatywnemu pisaniu, jak dziś zwykło się to określać w Polsce. W tym miejscu nasuwa się pytanie, od kiedy właściwie mówimy o sklasyfikowaniu wypowiedzi i uznaniu ich za formy dziennikarskie?

Badacze początków historii prasy upatrują już w czasach starożytnych, wtedy bowiem pojawily się pierwsze formy prymitywnego komunikowania masowego. Część z nich za poprzedników gazet uznaje ustanowione w 59 roku p. n. e. przez Juliusza Cezara Acta Diurna. Były to komunikaty rozwieszane w miejscach publicznych, zawierające ważne informacje dotyczące zarządzeń władz, nadchodzących uroczystości lub inne istotne doniesienia związane z funkcjonowaniem państwa. Technika takiego sposobu informowania okazała się skuteczna i wygodna dla obywateli. Inni za początkowy moment historii rozwoju gazet uznają wprowadzenie rozpowszechnianych od IV wieku w Chinach komunikatów

47 M. Chyliński, S. Russ-Mohl, Dziennikarstwo, s. 15.

48 Obecnie dziennikarze muszą doskonalić swój warsztat zawodowy, aby sprostać wymaganiom odbiorców, którzy są coraz bardziej wymagający, wyższe wykształcenie pozwala im bowiem na swobodne poruszanie się po medialnej przestrzeni: M. Chyliński, S. Russ-Mohl, Dziennikarstwo, s. 15.

49 Do najpopularniejszych należą: Jak zostać dziennikarzem (2007) Jarosława Ściślaka, dziennikarza i pisarza; Dziennikarstwo (2008) autorstwa Marka Chylińskiego, redaktora naczelnego „Dziennika Zachodniego” i Stephana Russ-Mohla, szwajcarskiego medioznawcy, dyrektora Europejskiego Obserwatorium Dziennikarskiego; Biblia dziennikarstwa (2010) pod red. Andrzeja Skworza i Andrzeja Niziołka, gromadząca artykuły najwybitniejszych postaci polskiego dziennikarstwa; To nie jest zawód dla cyników (2013), niepublikowane wcześniej w Polsce wykłady i rozmowy Ryszarda Kapuścińskiego, wydane wcześniej jedynie w języku włoskim i hiszpańskim; Kurs dziennikarstwa dla samouków (2014) autorstwa Małgorzaty Karoliny Piekarskiej, pracującej od wielu lat w mediach. Inni autorzy, których pozycje pomagają szlifować warsztat dziennikarski, to Walery Pisarek, Wiesław Godzic, Jerzy Bralczyk, Jacek Maziarski, Janina Fras czy Marek Ostrowski. Natomiast wśród twórców licznych naukowych opracowań dotyczących teorii komunikacji społecznej i historii mediów znajdują się: Tomasz Goban-Klas, Sylwester Dziki, Zbigniew Bajka, Bartłomiej Golka czy Maciej Mrozowski. 
zawierających treści dworskie, na przykład dekrety cesarskie, sprawozdania z posiedzeń. Pierwszy z prostych informatorów pt. „Dibao” - „Gazeta Dworu” - zaczął się ukazywać w formie drukowanej już w VII wieku, jego publikacji zaprzestano wraz z upadkiem cesarstwa w $1911 \mathrm{roku}^{50}$. Gazety początkowo ukazywały się okazjonalnie, cechowały się krótkotrwałością, powstawały bowiem na potrzeby chwili, a ich tematyka skupiała się głównie na sprawach kupieckich, w następnej kolejności na relacjach odnoszących się do nadzwyczajnych wydarzeń. Czasopisma rozpowszechniane nieregularnie i dokumentujące jakieś szczególne wydarzenie we Włoszech określano jako „avissi”, w Niemczech „neue zeitung”, z kolei w Polsce jako „nowiny” oraz „relacje” 51 przypominały one bowiem swoją strukturą listy, były jednak nie tyle czytane przez jednego adresata, ile udostępniane oficjalnie szerokiej grupie odbiorców. Sztuka epistolografii stanowiła w tym czasie platformę wymiany informacji oraz wyrażania poglądów. Trzeba zaznaczyć, że listy stanowiące substytut prasy różniły się nieco od tych tradycyjnych, zarówno w warstwie językowej, jak i treściowej. Zawsze były wytworem świadomej działalności piszącego, posiadającego szeroki dostęp do wiarygodnych źródeł informacji, traktującego swoją korespondencję w sposób profesjonalny. List musiał posiadać tytuł, charakteryzował się też brakiem zwrotów grzecznościowych, obecnych $\mathrm{w}$ pismach tradycyjnych, nie poruszano $\mathrm{w}$ nim również spraw osobi-

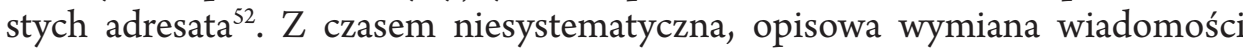
przekształciła się w permanentne narzędzie do informowania. List jest zatem jednym z najstarszych gatunków piśmiennictwa i komunikacji medialnej. Jednocześnie należy podkreślić, że pierwsze gazety przypominające pod względem kształtu listy można uznawać za dzieła z pogranicza literatury. Na gruncie polskim autorką fundamentalnej teorii listu jest Stefania Skwarczyńska. Rozważania autorki koncentrują się wokół ustaleń dotyczących aktu epistolarnego. Skwarczyńska zauważa, że pojęcie „list” można definiować na wielu płaszczyznach, jest to termin niejednoznaczny. List zawsze posiada jednak cechy formalne oraz znamienny styl, co nadaje mu historyczno- literackie znaczenie ${ }^{53}$. Sytuacja powiązana $\mathrm{z}$ rosnącą popularnością tego gatunku użytkowego miała też bezpośredni

so S. Dziki, Prasa w rozwoju historycznym, [w:] Dziennikarstwo i świat mediów, red. Z. Bauer, E. Chudziński, Kraków 2000, s. 32.

51 Pierwszą gazetą pisaną, która w całości ukazała się w języku polskim, były „Nowiny z Konstantynopola” w 1550 roku: S. Dziki, Prasa w rozwoju historycznym, s. 33.

52 Ibidem.

53 Studium pt. Teoria listu to szczególna pozycja w dorobku Stefanii Skwarczyńskiej. Pierwsze powojenne wydanie zostało przygotowane na podstawie lwowskiego pierwodruku z 1937 roku. W 2006 roku Teoria listu została wznowiona, dokonano w niej niezbędnego minimum redakcji tekstu, zweryfikowano i uzupełniono przypisy oraz opatrzono Słowem wstępu: S. Skwarczyńska, Teoria listu, oprac. E. Felisiak, M. Leś, Białystok 2006. 
związek z okresem wielkich odkryć geograficznych i podróży. Nową formę komunikacji usprawnily też dynamicznie rozwijające się ośrodki pocztowe. Wraz z upływem czasu i aktywizacją życia społecznego gazety pisane przestawały być wystarczającym kanałem przekazu informacji, rewolucję przyniosło dopiero wynalezienie prasy drukarskiej przez Jana Gutenberga w 1450 roku. Spopularyzowanie techniki ruchomej czcionki znacząco uprościło wydawanie czasopism i pozwoliło na regularną publikację, w ten sposób narodziła się ciągła działalność wydawnicza. Historycy prasy uważają początek XVIII wieku za okres rozkwitu nowoczesnego dziennikarstwa - wiązało się to bezpośrednio $\mathrm{z}$ wydarzeniami kulturalnymi (epoka oświecenia), społeczno-politycznymi (Wielka Rewolucja Francuska: 1789 oraz wcześniejsza rewolucja angielska: 1688-1689), techniczno-ekonomicznymi (rewolucja przemysłowa), charakterystycznymi dla tego przedziału czasowego. Wszystkie te czynniki wpłynęły na formułowanie się nowych struktur komunikacji oraz kierunek rozwoju stylów wiadomości dziennikarskich, a szeroko rozumiana sfera publiczna zaczęła przechodzić stopniową transformację. Wówczas pojawił się zupełnie nowy rodzaj prasy omawiający wydarzenia dnia codziennego, przykładem jest angielska gazeta „The Weekly Review" wydawana przez Daniela Defoe, którego nazwano pierwszym zawodowym dziennikarzem. Jeśli chodzi o pisarstwo to literatura w szczególny sposób zaczęła się łączyć z polityką i żurnalistyką, angażując wielu cenionych pisarzy ${ }^{54}$. Wzrastająca rola dziennikarstwa w kształtowaniu opinii publicznej przyczyniła się do powstawania nowych gatunków prasowych - głównie publicystyka zaczęła pełnić ważną misję. Polski prasoznawca Sylwester Dziki podkreśla, że w tym okresie wytworzył się zupełnie nowy model prasy „opartej na indywidualnościach dziennikarskich piór ( panujący w dziewiętnastowiecznej prasie, aż do momentu narodzin dziennikarstwa agencyjnego)" ${ }^{55}$. Publikowano liczne tak zwane czasopisma moralne, odpowiadające dzisiejszym tygodnikom opiniotwórczym. Do najbardziej poczytnych należał „Tatler” (1709) oraz „Spectator” $(1711-1714)^{56}$, w Polsce ich ekwiwalentem był „Monitor” ${ }^{57}$. Wtenczas ważne wiadomości zaczęły stawać się towarem cieszącym się ogromnym popytem, co sprawiło, że wzrastająca popularność gazet przyczyniła się do prawdziwego rozkwitu w obszarze dziennikarstwa. Społeczeństwu występującemu w charakterze odbiorcy nie wystarczały już krótkie formy piśmiennicze, a u wielu osób wykształcił się stały nawyk czytelnictwa. Wszystkie teksty wymagały dokładnego przemyślenia, a ich publikacja była możliwa po uprzednich dysputach dotyczą-

54 J. Habermas, Strukturalne przeobrażenia sfery publicznej, przeł. W. Lipnik, M. Łukasiewicz, Warszawa 2007, s. 16-23.

55 S. Dziki, Prasa w rozwoju historycznym, s. 34.

56 Ibidem.

57 Zob. Z. Sinko, „Monitor” wobec angielskiego „Spectatora”, Wrocław 1956. 
cych układu, formy oraz zawartości merytorycznej. Dla lepszego nakreślenia wagi przełomu w kulturze czytelnictwa zaistniałego w tym okresie zasadne wydaje się naszkicowanie w nieco szerszy sposób sytuacji kultury literackiej i samego uczestnictwa $\mathrm{w}$ niej, ta bowiem od zawsze była częścią sfery publicznej. Jedną $\mathrm{z}$ istotniejszych spraw, o których należy wspomnieć przy omawianiu rozwoju prasy są instytucje kawiarni, w nich bowiem wedle Jürgena Habermasa zachodził proces kształtowania się opinii publicznej. Dyskusje podejmowano przy filiżance gorącej herbaty, a następnie kawy, której pojawienie się w Europie wyjątkowo sprzyjało kontaktom obywatelskim i tworzeniu się wspólnot językowych. Kawiarnie stanowily społeczne punkty nowej kultury czytelniczej, pojawiającej się wraz ze wzrostem liczby pisarzy, produkcji książek i czasopism ${ }^{58}$. Publiczność kawiarniana traktowała dyskusję nad artykułami ukazującymi się w prasie jako obowiązkową składową swoich dysput. Wydawcy, widząc tak duże zainteresowanie, przedrukowywali co tydzień najpoczytniejsze teksty, co miało na celu podkreślenie ponadczasowej ciągłości procesu wzajemnego oświecenia się gości w kawiarniach $^{59}$. Habermas w książce Strukturalne przeobrażenia sfery publicznej (po raz pierwszy wydanej w 1962 roku) wymienia wyznaczniki charakteryzujące dawne kawiarnie, stanowiące ważny kontekst dla zilustrowania początków dziennikarstwa oraz narodzin nowożytnej sfery publicznej. Najważniejszym z nich był postulowany przez „domy kawy” rodzaj wzajemnego odnoszenia się do siebie gości. Zupełnie nieistotny okazywał się status uczestników spotkań, kawiarnia całkowicie od niego abstrahowała, nie celebrowano rang, przyjmowano równość osób wynikającą z samej racji urodzenia. Wyobraźnia, grzeczność i czytelnictwo były domenami uczestników kawiarnianych debat ${ }^{60}$. Spotkania zakładały problematyzację dziedzin, również tych przeznaczonych wyłącznie dla autorytetów kościelnych i państwowych. Stosunkowo późno zachodzą te procesy w Europie Środkowo-Wschodniej. Historyk literatury Stefan Kaszyński podkreśla: „dopiero po 1925 roku [w Polsce] pojawiła się tak zwana Café-Restaurant, kawiarnio-restauracja, a wraz z nią klasyczna atmosfera kawiarni doznała faktycznie radykalnego wstrząsu"61. Stopniowo następował rozpad obywatelskiej sfery publicznej oraz ekspansja pewnych modeli komunikacji. Wygaszenie obywatelskiego uczestnictwa w sferze publicznej oraz wpływ nowo powstających i szybko rozwi-

58 Co ciekawe, pierwszy włoski periodyk nazywał się „Il Caffe”. Jego założycielami byli myśliciele oświecenia z Lombardii. „Il Caffe” poruszało na swoich łamach zróżnicowaną tematykę, od życia artystycznego po sprawy socjalne.

59 J. Habermas, Strukturalne przeobrażenia..., s. 16-23, 120-121.

60 Szerzej na ten temat zob. J. Płuciennik, Literatura, głupcze! Laboratoria nowoczesnej kultury literackiej, (rozdz. I: Laboratorium nowoczesnej podmiotowości. Oświecenie i niekończąca się opowieść literatury), Kraków 2009, s. 23-50.

61 S. H. Kaszyński, Opowieści wiedeńskiej kawiarni, Poznań 2004, s. 23. 
jających się środków masowego przekazu przyczyniły się do ogromnych zmian w procesie kształtowania opinii publicznej. Rozdysputowana publiczność została przekomponowana w bierną masą konsumentów, a w związku z tym również prasa zaczęła dostosowywać swój styl pisania do preferencji i potrzeb nowej grupy odbiorców. Najbardziej symptomatyczną i niepokojącą zmianą, jaka zaszła w praktykach komunikacyjnych, było zmniejszenie się dystansu pomiędzy oficjalną i nieoficjalną odmianą języka, czego głównym przejawem stała się ekspansja potoczności w większości tekstów dziennikarskich ${ }^{62}$. Habermas postawił diagnozę prostoliniowego rozwoju publiczności: „od aktywnej politycznie do prywatystycznej, od rozprawiającej o kulturze do konsumującej kulturę”. W Przedmowie do nowego wydania z 1990 roku książki Strukturalne przeobrażenia sfery publicznej wyraził opinię, że było to rozpoznanie zbyt uproszczone, z czym nie do końca można się zgodzić, filozof trafnie scharakteryzował przemianę, krytykując zmiany w postawach jednostek. Najważniejszy jest dokonywany indywidualnie rozdział w obszarze prywatności na interesy, które załatwia się samodzielnie, oraz na sprawy, które porusza się podczas szczególnego obcowania z innymi ludźmi, z którymi wówczas tworzy się publiczność. Niestety próg owego podziału przesuwał się wraz z zanikaniem literackiej sfery publicznej, a pojawianiem się sfery konsumpcyjnej. Następowało psychospołeczne przekształcenie funkcji pierwotnego związku pomiędzy płaszczyzną intymną a literackim obszarem publicznym ${ }^{63}$.

Podejmowany przez Habermasa problem oddzielenia lub też zespolenia sfery publicznej i prywatnej odnajdujemy w zarysie, w nieco zaskakujący sposób, także w pismach jednego z największych myślicieli antyku - Horacego. W twórczości rzymskiego poety bardzo ważną pozycję stanowią Listy, zawierające pochwałę boskiej mądrości (caelestis sapientia) wiodącej ludzi do doskonałości moralnej. Wśród Listów dotyczących zagadnień literackich i filozoficznych najważniejszy jest List do Pizonów (datowany na 20-19 rok p.n.e.) nazwany po raz pierwszy przez Kwintyliana „księgą o sztuce poetyckiej” - De arte poëtica ${ }^{64}$. Jest to wierszowany traktat o twórczości poetyckiej zawierający szereg praktycznych rad dla poetów. List do Pizonów składa się z czterystu siedemdziesięciu sześciu wierszy i pomimo pozornej dowolności w układzie można w nim dostrzec pewien schemat podręcznikowy, wprowadzający w ważne dziedziny, jakimi są retoryka i poetyka. Fragment początkowy zawiera opis elementów, z których zbudowany jest tekst (tractatio, inventio, dispositio, elocutio), oraz wiedzę o rodzajach poezji,

62 T. Piekot, Dyskurs polskich wiadomości prasowych, Kraków 2006, s. 58.

63 J. Habermas, Strukturalne przeobrażenia..., s. 307-310.

64 Znany także pod nazwą Sztuka poetycka: Horacy, List do Pizonów, [w:] Trzy poetyki klasyczne: Arystoteles, Horacy, Pseudo-Longinos, przeł. i wstęp T. Sinko, Kraków 1951 , s. 25. 
$\mathrm{w}$ dalszej części zawarte są uwagi o wykształceniu oraz obowiązkach poety ${ }^{65}$. Horacy stara się wytłumaczyć, kim według niego jest poeta doskonały, prezentując wykaz typowych cech. List do Pizonów uważany jest za jeden z najważniejszych tekstów - jest tekstem „formułującym zasady stylu klasycznego ${ }^{66}$, czyli opartego na harmonii, znajomości tradycji i zachowującego wewnętrzny umiar" ${ }^{67}$. Ta niedługa rozprawa $\mathrm{w}$ dużej mierze przyczyniła się do określania Horacego mianem klasyka literatury europejskiej. Rzymski poeta w następujący sposób opisuje umiejętność i ważność oddzielania problemów natury prywatnej od publicznej:

Rzecz albo odbywa się na scenie, albo się opowiada o tym, co zaszło. Słabiej wzrusza umysły to, co wchodzi uszami, niż to, co podpada pod wierne oczy i co widz sam sobie opowiada. Nie wprowadzaj jednak na scenę rzeczy, które powinny się odbywać za kulisami, i usuń sprzed oczu niejedno, co wnet ma przedstawić wymowa obecnego przy tym zwiastuna. Niech więc Medea nie zabija dzieci wobec publiczności, zbrodniczy Atreus niech nie warzy otwarcie wnętrzności dzieci, Prokne niech się nie zamienia w ptaka, a Kadmus w węża: Cokolwiek mi tak pokażesz, nie wierzę $\mathrm{w}$ to i nienawidzę tego ${ }^{68}$.

Horacy podkreśla, że indywidualne troski i zainteresowania jednostek, a w tym znanych osobistości (we fragmencie padają imiona bohaterów mitologii greckiej: Medea - królowa kolchidzka, która zabiła swoje potomstwo w imię zemsty; Atreus - król Myken, który mszcząc się, zamordował dzieci swojego brata, a następnie podał mu z nich potrawę, historia znana jako „uczta Tyestesa” ${ }^{69}$; Prokne - córka Pandiona z Aten, która wraz z siostrą odebrała życie synowi króla trackiego Tereusa) ${ }^{70}$, nigdy nie powinny pojawiać się w przestrzeni publicznej. Autor akcentuje również swoją niewiarę w szczerość intencji nadawcy jako twórcy podejmującego katastrofalną, a zarazem sensacyjną tematykę. Horacy buntuje się przeciwko pokazywaniu okrucieństw, szokujących widza oraz wywoływaniu ordynarnych reakcji. W dalszej części Listu do Pizonów Horacy jeszcze raz podkreśla istotę problemu sfer: „Istniała niegdyś ta mądrość, by sprawy publiczne oddzielać od prywatnych, święte od świeckich [... $]^{\text {”1 }}$. Rzymski myśliciel tłumaczy, że do sfery ogólnodostępnej nie powinny trafiać zagadnienia związane z pry-

${ }^{65}$ Horacy, List do Pizonów, s. 21.

${ }^{66} \mathrm{O}$ współczesnej definicji stylu klasycznego zob. T. Francis-Noël, M. Turner, Clear and Simple As the Truth: Writing Classic Prose, Princeton 2011.

${ }^{67}$ M. Hanczakowski i in., Epoki literackie. Od antyku do wspótczesności, Bielsko-Biała 2002. s. 35 .

${ }^{68}$ Horacy, List do Pizonów, s. 74-75.

${ }^{69}$ Zob. W. Kopaliński, Stownik mitów i tradycji kultury, Warszawa 1985.

${ }^{70}$ Horacy, List do Pizonów, s. 70-74.

${ }^{71}$ Ibidem, s. 85. 
watnym życiem znanych person, wtedy bowiem z dyskursu publicznego wypychane jest to, co jest naprawdę ważne dla społeczności, a na scenę jawną trafiają sprawy, które nigdy nie powinny się tam znaleźć.

Zarówno Habermas, jak i Horacy zgadzają się, że obie domeny - publiczna i prywatna - powinny się znajdować w stabilnej równowadze, ponieważ ich funkcjonowanie określają wyraźne reguły. Przez kolejne lata szereg zapatrywań dotyczących literatury, jej sposobów istnienia, właściwości i zobowiązań charakterystycznych dla danych grup społecznych, w tym także status odbiorców, zmieniał się, również prasa przechodziła dalszą transformację. W XIX wieku etapy jej rozwoju wyznaczały chociażby ruchy społeczne, które spowodowały szerokie zróżnicowanie typologiczne czasopism, publikowano między innymi: prasę zawodową, magazyny kobiece, dziecięce, naukowe oraz ilustrowane. Kamieniem milowym była modernizacja sztuki drukarskiej, co pozwoliło na kolportaż prasy kolorowej, wzbogaconej obrazem. Sektor prasy komercyjnej został przyjęty $\mathrm{z}$ aprobatą przez społeczeństwo, a jego rozwój postępował dynamicznie, wówczas ukazywały się tak zwane gazety niedzielne - typ ogólnoinformacyjny zawierający aktualności z ostatnich dwudziestu czterech godzin, komentarze do bieżących wydarzeń oraz obszerną część analityczną. Nowość stanowiło publikowanie treści rozrywkowych, co widoczne było na przykład w „Sunday Monitor” (1780) ${ }^{72}$. Do prasy niedzielnej należały też czasopisma odznaczające się wysokim poziomem publicystyki społeczno-kulturalnej, wśród nich jednym z najbardziej poczytnych i zarazem cieszącym się dużym uznaniem w kręgach intelektualnych, politycznych oraz rządowych był „Observer”. Gazeta ta niewątpliwie zalicza się do kanonu jakościowego dziennikarstwa, ceniącego prawdomówność oraz rzetelność. Wraz z masowym rozwojem prasy komercyjnej pojawiały się też nowe metody piśmiennicze, spadało zainteresowanie czasopismami opiniotwórczymi, wydawcy magazynów zaczęli kierować się ustalonym przez siebie kanonem wartości i własnymi zasadami (pierwsze strony miały być zapełnione aktualnymi wydarzeniami, na następnych miały widnieć materiały naukowe, zdarzenia sensacyjne, plotki ze świata kultury, porady oraz krótkie historyjki w postaci komiksów). W końcu w kontekście prasy narodziło się pojęcie yellow journalism - „żółte dziennikarstwo" - które funkcjonowało w latach osiemdziesiątych XIX wieku i było stosowane na określenie sensacyjnej prasy. Nazwa pochodzi od żółtego koloru komiksów „The Yellow Kid”, których bohaterem był mały, żółty brzdąc. Za główne przykłady pism stosujących tego typu dziennikarstwa uznawano między innymi amerykańskie gazety „Sunday World” Josepha Pulitzera oraz „New York Journal American” Williama Randolpha Hearsta ${ }^{73}$.

${ }_{72}$ S. Dziki, Prasa w rozwoju historycznym, s. 35.

73 Ibidem, s. 35. 
Interesującym zjawiskiem widocznym już na tym etapie rozwoju dziennikarstwa jest swoista polaryzacja dwóch poziomów piśmiennictwa: pierwszy charakteryzujący się dokładnością, dialogowością, wysoką jakością przekazu oraz drugi odznaczający się nieetycznością, zależnością i monologowością. Sylwester Dziki podkreśla: „Pod koniec XIX wieku można już mówić o prasie jako środku masowego komunikowania"74. Rynek wydawniczy XX wieku zdominowały wysokonakładowe ilustrowane czasopisma wielkoformatowe o treściach sensacyjnych, określane jako tabloidy. Redaktorzy posługiwali się „lekkostrawnymi” technika$\mathrm{mi}$, jak news picture, cartoon, human interest story czy fiction stories, dając odbiorcy wszystkie wskazówki umożliwiające mu zrozumienie przekazu. Wydawcy prasy zorientowali się, że można nie tylko kształtować opinię publiczną, ale przede wszystkim dostarczać rozrywkę, co przynosi znacznie wyższe zyski. Również w tej sprawie odnajdujemy stanowisko Horacego w jego Liście do Pizonów:

Utwory nie przynoszące pożytku ganią klasy starszych wyborców, a dumni rycerze młodsi pomijają surowe poematy; wszystkie głosy uzyskuje ten, kto połączy pożytek z przyjemnością, bawiąc czytelnika a zarazem go ucząc. Taka książka daje dochody księgarzom, taka za morze wędruje i przedłuża życie sławnego pisarza na wieki ${ }^{75}$.

Horacy wielokrotnie wspomina, jak ważna jest nauka, tłumacząc, dokąd może prowadzić wiedza i niewiedza. Autor pisze o istotności doboru słów, jasności układu tekstu, zwracając szczególną uwagę na miarę długości publikacji i znaczenie wyrazów zwyczajowych - nieozdobnych - których nadmierna liczba może zakłócać odbiór tekstu. Horacy poucza, że każdy rodzaj wypowiedzi powinien być dokładnie dopasowany do tematu, a chcąc osiągnąć jakiś cel i próbując wyprzedzić innych, należy postępować rozsądnie, nieustannie pamiętając o ideale, do którego zmierzamy. Ostatnia uwaga wydaje się priorytetowa dla zawodu żurnalisty, powinien on zawsze posiadać określony plan na przedstawienie konkretnego problemu, a jego artykuł powinien być spójną wypowiedzią. Horacy krytykuje przede wszystkim niedbalstwo i lenistwo w pracy pisarza. Fundamentalną kwestią dla rzymskiego poety jest także poznanie potencjalnych odbiorców, autor powinien starać się zrozumieć ich obyczaje i potrzeby, bowiem różni ludzie mają odmienne dążenia i pragnienia, zależnie od wieku, wykształcenia, statusu społecznego.

Prasoznawcy podkreślają, że wraz z ekspansją czasopism zatarciu ulegały różnice między gatunkami dziennikarskimi, które początkowo dokonały konkretnych podziałów. Obok tekstów w miarę trwałych pod względem struktury i formy językowej, pojawily się zupełnie nowe typy wypowiedzi,

\footnotetext{
74 S. Dziki, Prasa w rozwoju historycznym, s. 37.

75 Horacy, List do Pizonów, s. 83.
} 
charakteryzujące się różnym stopniem strukturalnej, pragmatycznej i stylistycznej złożoności. Badacze, w sąsiedztwie podstawowych gatunków informacyjnych i publicystycznych, zaczęli wyróżniać gatunki pograniczne, uznając je za spokrewnione $\mathrm{z}$ literaturą lub piśmiennictwem naukowym ${ }^{76}$. Jednym z najprostszych ze względu na stopień skomplikowania budowy stał się rodzaj informacji określany jako news, będący krótkim, zwięzłym tekstem, obejmującym zaledwie kilka zdań. News powstaje w oparciu o zasady utartego schematu i standardów językowych, stąd łatwo go stworzyć. W tym miejscu warto podkreślić, że sformułowanie „dziennikarz” nie jest zdefiniowanym i chronionym określeniem regulowanego zawodu, a Konstytucja Rzeczpospolitej Polskiej zapewnia wolność słowa, opinii oraz prasy. W związku z tym dziennikarzem może być tak naprawdę każdy, kto gromadzi, przetwarza i publikuje materiały medialne ${ }^{77}$. Współcześnie dodatkowym problemem jest zmiana nośników przekazów komunikacyjnych oraz szybki rozwój nowych technologii, co przyniosło rozkwit tak zwanego dziennikarstwa obywatelskiego. Nowoczesne technologie zapoczątkowały nową jakość, która pasywnego odbiorcę przemieniła w aktywnego współtwórcę przekazów, doprowadzając do zauważalnych i brzemiennych w skutki zmian w obrębie określonych praktyk komunikacyjnych. Dziś jesteśmy aktywnymi świadkami ewolucji słowa pisanego i mówionego. Łatwy dostęp do urządzeń elektronicznych aktywizuje miliony ludzi spragnionych dzielenia się własną indywidualnością, jakąkolwiek medialną obecnością, niezależnie od poziomu intelektualnego. Wykorzystywanie takich platform, jak Twitter i Facebook, wzrasta z zawrotną prędkością, bowiem są to pierwsze powszechnie dostępne narzędzia komunikacyjne, które pozwalają na bezpośrednie wyrażenie swoich poglądów, dając (lub zabierając) szansę na pominięcie całego łańcucha komunikacyjnego wpływającego na kształtowanie ostatecznej formy wypowiedzi. Platformy te umożliwiły komunikowanie się poza tradycyjnymi mediami, pozwalając na interakcję i wejście $\mathrm{w}$ natychmiastowy dialog $\mathrm{z}$ autorem. Jednakowoż mnogość płynących komunikatów skłania do refleksji nad jakością przekazów informacyjnych. Podążając tropem myśli Horacego, w Liście do Pizonów odnajdujemy fragment odnoszący się do tworzących poetów, uwagi te można jednak odnieść do zawodu dziennikarza, bowiem głównym narzędziem pracy przedstawicieli obu grup jest język:

Dla miernych poetów nie ma miejsca. A jak do gier nie przystępują nie znający ich reguł, tak do poezji nie powinni się brać ludzie bez fachowego przygotowania. Tymczasem w Rzymie pisze wiersze pierwszy lepszy zamożny obywatel, którego stać na opłacanie słuchaczy i chwalców - pochlebców. Pizon będzie wolał poddawać swe

76 M. Wojtak, Gatunki prasowe, Lublin 2004, s. 7.

77 M. Chyliński, S. Russ-Mohl, Dziennikarstwo, s. 18. 
utwory znawcom i nie będzie się śpieszył z ich ogłaszaniem. Poezja była z początku nauczycielką ludzkości, krzewicielką kultury. Sława z niej płynąca powinna utalentowanym poetom dodawać bodźca do starannej pracy, zadowolone z siebie nieuctwo nie wyda $\mathrm{z}$ siebie nic znacznego ${ }^{78}$.

Horacy akcentuje, że poeci powinni znać szczegółowe reguły umożliwiające tworzenie poezji. Osoby bez odpowiedniej wiedzy nie powinny pisać. Podczas procesu twórczego należy pamiętać, że z opublikowanych tekstów będą korzystać i czerpać mądrość w przyszłości inni ludzie. Ważna jest edycja, redakcja, dokładność i uważność podczas pisania. Autor zwraca uwagę, że obok wykwalifikowanych pisarzy istnieją też tacy, którzy nie mają doświadczenia, a ponadto nie chcą doskonalić swoich umiejętności. Podkreśla też, że nie należy się śpieszyć z ogłaszaniem niedopracowanych tekstów, pisarstwo wymaga bowiem refleksji i dogłębnego przemyślenia. Podobne zasady zatem powinny obowiązywać podczas tworzenia tekstów dziennikarskich, gdyż „[s]tyl tekstu dziennikarskiego polega na określonym wyborze środków językowych (słownikowych, gramatycznych) i ich szczególnej organizacji ${ }^{79}$, a do dobrego jakościowo dziennikarstwa niezbędna jest znajomość wszystkich tych elementów. W przypadku przywoływanego newsa istotna jest natychmiastowość, najważniejsze jest to, kto pierwszy podzieli się zdobytą informacją, stąd zdarza się, że nowiny podawane do wiadomości publicznej mogą być nieprawdziwe, często zachodzą również pomyłki, gdyż dziennikarze nie weryfikują zebranych danych. W konsekwencji news jest gatunkiem dziennikarskim o niskiej jakości językowej. Maria Wojtak, w której kręgu zainteresowań znajduje się stylistyka (teoretyczna, praktyczna), historia i kultura języka oraz prasoznawstwo, powołując się na Wstęp do nauki o literaturze Stefanii Skwarczyńskiej, podkreśla, że niezwykle ważna jest „potrzeba syntetyzującego ujęcia wyznaczników, wyodrębnienia konwencji, które czynią z gatunku jakość komunikacyjną, a więc także społeczną i kulturową" ${ }^{30}$. Marek Chyliński i Stephan Russ-Mohl uważają, że dziś „istnieją tylko dwa rodzaje dziennikarstwa niezależnie od stosowanych narzędzi - dobre albo złe" ${ }^{\text {"1 }}$. Opisując współczesny obraz piśmiennictwa od strony kulturoznawczej i językoznawczej, warto się zastanowić, czym jest jakościowe dziennikarstwo lub - szerzej - jakościowa komunikacja oraz jakie style ją charakteryzują.

Jednym z podstawowych założeń współczesnego językoznawstwa jest to, że nie istnieją teksty stylistycznie nienacechowane, każda wypowiedź ma bowiem styl lub też w jakimś stylu funkcjonuje. Styl można rozumieć jako „zbiór

78 Horacy, List do Pizonów, s. 25.

79 J. Fras, Dziennikarski warsztat językowy, Wrocław 1999, s. 11.

80 M. Wojtak, Gatunki prasowe, s. 13.

${ }^{81}$ M. Chyliński, S. Russ-Mohl, Dziennikarstwo, s. 12. 
najbardziej charakterystycznych (najczęściej leksykalno-składniowych) cech tekstu lub też jako światopoglądową ramę, która decyduje o sposobie kodowania i dekodowania wypowiedzi. Pierwsze podejście reprezentuje normatywną, drugie kulturowo-językową koncepcję stylu"82. Początkowo zawód dziennikarza traktowany był jako swego rodzaju misja i wiązał się z rzetelnym przekazywaniem informacji społeczeństwu. Wśród wielkich dziennikarzy wymienia się Charlesa Dickensa, Fiodora Dostojewskiego czy Bolesława Prusa; problemu nie stanowił opis reprezentowanego przez każdego z nich stylu. W zasadzie już od czasów Daniela Defoe pisarze bywali także dziennikarzami, a „doświadczenie żurnalistyczne” przekładało się u nich chociażby na odnajdywanie porywających, czasem sensacyjnych tematów literackich. Dziś style, technika oraz specyfika zawodu dziennikarskiego nieco się zmieniły. Polski prasoznawca Walery Pisarek proponuje kilka określeń na współczesnych dziennikarzy. W zależności od przypisywanych im cech wyróżnia: bojowników - zdeklarowanych misjonarzy piszących wyłącznie „we własnej sprawie”; dyskdżokejów - zabawiających czytelników oraz rzemieślników - grupę profesjonalistów w swoim zawodzie $^{83}$, podkreślając, że mamy do czynienia z sytuacją obniżenia jakości tekstów dziennikarskich. W Wielkiej Brytanii wciąż funkcjonuje określenie quality paper, które oznacza prasę posiadającą wysokie standardy edytorskie, na której łamach drukowane są wyłącznie artykuły poruszające kwestie istotne dla społeczeństwa, złożone z dogłębnej analizy i obszernych komentarzy. Powstają jednak nowe rodzaje dziennikarstwa, chociażby takie, jak wspomniane: citizen journalism, civic journalism oraz gossip journalism czy gonzo journalism, będące odpowiedzią na potrzeby współczesnych odbiorców. Specyfikę funkcjonowania dzisiejszej prasy prezentuje w interesujący sposób Umberto Eco w analizowanej w początkowej części artykułu powieści Temat na pierwsza stronę. Mediewista przedstawia subiektywną wizję zależnego dziennikarstwa, podkreślając, że media kierują się określonymi zasadami, na przykład według „New York Times”: „all the news that's fit to print”: („w prasie ukażą się wszystkie wiadomości, które nadają się do druku").

Rzecz w tym, że gazety nie służą rozpowszechnianiu wiadomości, służą ich ukrywaniu. Zdarza się fakt $x$, ty nie możesz o nim nie napisać, ale zbyt wielu ludziom sprawia kłopot, więc w tym numerze umieszczasz wielkie tytuły, od których włosy stają dęba $[\ldots]$, wtedy tamta wiadomość tonie w morzu informacji ${ }^{84}$.

82 T. Piekot, Dyskurs polskich wiadomości..., s. 23.

83 Z. Bajka, Dziennikarze lat dziewięćdziesiątych, „Zeszyty Prasoznawcze” 2000, nr 3-4, s. 58-59.

${ }^{84}$ U. Eco, Temat na..., s. 140. 
Informacje są selekcjonowane, a komunikaty ukazujące się w prasie często wymazują problemy dnia wczorajszego. Odpowiednie słowa urozmaicają artykuły, często upodabniając je do opowiadań, przez co trudno rozróżnić, która część jest prawdą, a która fikcją. Żyjemy w kulturze wielomedialnej, zmiennej, w której permanentnie zaciera się granica między rozrywką a informacją. Ogromna ilość treści zamieszczana w obrębie jednej gazety (najbardziej widoczne jest to w prasie codziennej), sprawia, że zamieszczone w niej aktualności stają się nierzadko chaotyczne. Mimo pozornego uporządkowania gazeta staje się wymieszanym zbiorem informacji - gdzie duża liczba tytułów, nagłówków, wlepek, infografik, wyimków czy zapowiedzi składa się na jej fragmentaryczność, wielogatunkowość oraz wielostylowość. Jakość przekazów, różnorodność stylów, a także badania nad piśmiennictwem stały się ostatnio jednymi z najczęściej dyskutowanych problemów w obszarze szeroko rozumianej nauki o komunikowaniu ${ }^{85}$. Eco krytykuje dziennikarzy udzielających głosu wyłącznie tym, którzy prezentują poglądy zgodne z ich przekonaniami. Pisarz jako kontrargument podkreśla, że w gazecie powinny być zamieszczane opinie osób pochodzących z różnych środowisk, przedstawiających odmienne światopoglądy. Mediewista sporo uwag kieruje $\mathrm{w}$ stronę problemu ujednolicenia języka w prasie oraz podejmowanej tematyce, dobieranej w taki sposób, aby odpowiadała jak największej liczbie odbiorców. Problem stanowi również zmniejszająca się liczba dziennikarzy w redakcjach, gdzie jedna osoba staje się odpowiedzialna za kilka działów tematycznych, pisząc jednocześnie nekrologi, horoskopy, teksty polityczne, ekonomiczne i naukowe. Eco zauważa, że jeszcze kilka lat temu teksty dziennikarskie były dokładnie analizowane, w każdej redakcji była osoba na stanowisku korektora, a dodatkowo pracownik sprawdzający wiarygodność informacji ( na przykład w encyklopedii daty i nazwiska). Ponadto włoski pisarz językiem przepełnionym ironią opisuje lokalizację współczesnych redakcji wielkich dzienników, redakcji mieszczących się na peryferiach miasta, dokąd dojeżdża się kilkoma środkami komunikacji. W dalszej części podkreśla, że aby stworzyć dobry jakościowo tekst dziennikarski, trzeba się ruszać, odwiedzać miejsca, osoby, przeprowadzić rozmowy, zrobić research i umiejętnie połączyć zebrane dane w całość. Filozof zwraca uwagę na zmianę narzędzi w pracy dziennikarskiej i wykorzystywanie nowych technologii: „Różnych szuflad i szafy w przedpokoju nie warto nawet otwierać. Jeśli czegoś szukali, to w dzisiejszych czasach musieli zrobić tylko jedno - pogrzebać w komputerze" ${ }^{86}$. Eco krytykuje nie tylko dziennikarzy, ale także odbiorców prasy, zarzucając im brak wiedzy, kompetencji i aktywności związanej z czytelnictwem. Wspomina o popularności informacji posiadających „skandaliczny posmak”, dodając,

Ibidem, s. 105-106.

86 U. Eco, Temat na..., s. 10.

87 Ibidem, s. 28. 
że z czasopism znikają rubryki poświęcone kulturze, a przeważają te z sensacją. W kontekście tych ostatnich przytacza niemieckie słowo Schadenfreude, oznaczające zadowolenie z cudzego nieszczęścia, akcentując, że takie emocje obecna prasa stara się prezentować swoim czytelnikom ${ }^{88}$.

Współczesny stan piśmiennictwa komentuje również Steven Pinker w jednej ze swoich ostatnich publikacji Piękny styl. Przewodnik człowieka myślącego po sztuce pisania XXI wieku $(2015)^{89}$, poświęconej w całości kunsztowi tworzenia przejrzystych, spójnych i stylowych treści ${ }^{90}$. Badacz podkreśla, że nowożytni pisarze nie mogą korzystać $\mathrm{z}$ rad autorów (odwołuje się do uznawanego za ponadczasowe dzieła The Elements of Style [1918], autorstwa Williama Strunka i Elwyna Brooksa White’a) analizujących kompozycję tekstów kilka dekad wcześniej, przed wynalezieniem telefonu, Internetu, a także przed pojawieniem się nowoczesnej lingwistyki oraz nauk kognitywnych. Pinker w centrum zainteresowań stawia język, twierdząc, że piszący powinni dostosowywać się do potrzeb czytelników konkretnej epoki. Posługując się metaforą, zauważa, że język to nie jest „protokól” zalegalizowany przez autorytety, ale twór nieustannie zmieniający się wraz z potrzebami ludzi i okresu, w jakim się żyje. Konkretne zbiorowości zakorzeniają w języku nowe słowa, o czym zapominają kreatorzy purystycznych stylistycznie książek. Zabawne jest, że podobną cechę języka zauważa już Horacy w Liście do Pizonów: „Wolno było i zawsze będzie wolno kuć wyrazy znaczone stemplem współczesności. Jak na drzewach zmieniają się liście w biegu mknących lat, jedne opadają, drugie rosną, tak ginie stare pokolenie słów, a nowo narodzone kwitną i bujają na wzór młodzieńców"91.

Zarówno Eco, jak i Pinker niejednokrotnie podkreślali, że aby zostać dobrym pisarzem, trzeba być początkowo zachłannym czytelnikiem, podobne stanowisko prezentuje Horacy: „Wy, Pizonowie pierwowzory greckie bierzcie do rąk, i czytajcie i w nocy i w dzień" ${ }^{22}$. Autorzy twierdzą, że pisarz dopiero po wielu lekturach może nabyć pewne sprawności, jak: spostrzegawczość, dokładność, wrażliwość autorska czy oryginalność w postrzeganiu - nie chodzi o naśladownictwo innych, ale o naukę kluczowej kompetencji wyciągania własnych wniosków. Myśliciele zwracają uwagę na pewne nawyki, których wyrobienie, a następnie przestrzeganie pozwoli na wyższą jakość wykonywania profesji pisarskiej.

88 U. Eco, Temat na..., s. 125.

89 S. Pinker, The Sense of Style: The Thinking Person's Guide to Writing in the $21^{\text {st }}$ Century, London 2014.

90 S. Pinker, Piękny styl. Przewodnik człowieka myślącego po sztuce pisania XXI wieku, przeł. A. Nowak-Młynikowska, Sopot 2015.

91 Horacy, List do Piznonów, s. 68.

92 Ibidem, s. 79. 
Każda epoka historyczna cechowała się określonymi odkryciami, wydarzeniami, poglądami na świat, a także niejednakową dynamiką rozwoju literatury i piśmiennictwa. Jako że nas interesuje współczesny stan prasy, to wydaje się, że dla opisu i uporządkowania tak różnorodnego środowiska kultury piśmienności kluczowe będzie zdefiniowanie dwóch modeli komunikacyjnych, dających się scharakteryzować po sposobie istnienia ekspresji językowej, rozumianych jako style. Aby te modele dookreślić, można wyjść od antycznego zarysu w końcowej części Listu do Pizonów Horacego, w której odnajdujemy bezpośrednio rozróżnienie dwóch sposobów pisania. Rzymski poeta twierdzi, że początkiem i źródłem dobrego pisania jest mądrość, a nie szaleństwo, jak uważał Demokryt z Abdery (460-370 n.e.) utrzymujący, że źródłem poezji jest „szał” (mania, łac. furor) ${ }^{93}$, stanowiący rodzaj natchnienia wieszczego ${ }^{94}$. W kontekście tego drugiego możemy usytuować styl dziennikarstwa nazywanego, nomen omen, gonzo (hiszpańskie ganso - dosłownie „gęs’”, prostak, nieuk, głupiec, człowiek niechlujny, włoskie gonzo - „wariat, szaleniec”), charakteryzującego się skrajnym subiektywizmem oraz luźnym podejściem do faktów. Styl gonzo jest zuchwały, satyryczny, ekstrawagancki, szalony. W dziennikarstwie gonzo istotne jest podkreślenie literackiego charakteru tekstów, zarówno w zakresie samego stylu, jak i obecności elementów fikcji. Gonzo można traktować jako wariant zarówno literatury fiction, jak i non-fiction. Bezpośrednio w kontekście dziennikarstwa pojęcie „gonzo” pojawiło się w 1970 roku, od tamtej pory styl ten jest też kojarzony z nurtem tak zwanego Nowego Dziennikarstwa, zapoczątkowanego w latach sześćdziesiątych i siedemdziesiątych w Stanach Zjednoczonych. Wówczas w zakresie kompozycji tekstu odrzucono większość reguł uważanych za niezbędne do tworzenia wysokojakościowych tekstów dziennikarskich ${ }^{95}$. Wracając do pierwszego modelu, zacytujmy Horacego: „źródłem dobrej poezji jest rozsądek. Poznanie etyki umożliwia tworzenie poematów, które, mimo braków artystycznych, większe wywołują wrażenie niż puste, choć pięknie brzmiące wierszydła" ${ }^{96}$. Zatem opozycją dla stylu przesyconego sensacją, intuicyjnego i emfatycznego, jakiego najczęściej oczekuje współczesny odbiorca prasy, jest styl etyczny, deliberacyjny, którego cechą dominującą jest analityczność i bezstronność, rozpatrywane w kategoriach jakości dyskursu. W takich tekstach dominuje rozsądek, a twórca kładzie nacisk na stronę formalną, jest to rodzaj twórczości „rozumowej”, kierującej się określonymi regułami ${ }^{97}$.

93 Horacy, List do Pizonów, s. 81.

94 Co można rozpatrywać również w kontekście teorii wzniosłości o szaleństwie: zob. J. Płuciennik, Retoryka wzniosłości w dziele literackim, Kraków 2000.

95 I. Adamczewska, Gonzo journalism, „Zagadnienia Rodzajów Literackich” 2014, t. 57, z. 1, s. 341-343.

${ }^{96}$ Horacy, List do Pizonów, s. 24.

97 Więcej na temat bezstronności, ideału „bezstronnego obserwatora” oraz o nurcie analitycznym zob. J. Płuciennik, Literatura, glupcze!... 
Zaglądając do poetyki klasycznej Horacego można - nieco na przekór współczesności, która często zapomina o historii - wyprowadzić aktualne reguły dla pisarstwa (w tym dziennikarstwa). Pomimo tego, że Horacy tworzył w odmiennych od obecnych warunkach społecznych i politycznych, jego spostrzeżenia można odnieść do pewnego stopnia do współczesnych metod tworzenia tekstu. Dzisiejsi autorzy tekstów dziennikarskich dostosowują się jedynie do potrzeb czytelniczych, poczucia grupowości i wspólnotowości. W tym przypadku względy społeczne dominują nad względami literackimi, stąd rezygnuje się z językowej wirtuozerii na rzecz języka prostego, a zarazem przyciągającego uwagę. Możemy zatem mówić o sytuacji przeistaczania się stylów oraz praktyk dziennikarskich.

Kwestia stylu kojarzona jest nieodparcie z zagadnieniem obrazowania i oddziaływania językowego, przez co stanowi ona istotny element badań literackich, językoznawczych oraz medioznawczych. W wyniku przeprowadzonych analiz wydaje się, że odwołania do piszącego o poezji Horacego są pewnym nadużyciem, podobnie jak nazywanie dziennikarstwa literaturą ${ }^{98}$, choć coraz częściej czerpie ono techniki literackie (strumień świadomości, zróżnicowanie stylistyczne) z beletrystyki ${ }^{99}$. Takie ujęcie niewątpliwie nobilituje dziennikarstwo, ale jednocześnie degraduje, odbierając mu medialną i kulturową specyfikę, która pojawiła się już w starożytności. Jeśli zatem zbliżyć się do literatury, to możemy powiedzieć, że dziennikarstwo jest jedną z postaci, jaką przybiera twórczość piśmienna. Horacy starał się zaprezentować obraz doskonałego twórcy (poeta od poesis), który jest świadomy nie tylko problemów artystycznych, ale także odpowiedzialności społecznej, ten zaś aspekt wydaje się dziś kluczowy dla dzienni-

${ }^{98}$ Umberto Eco stanowczo podkreśla różnicę: „Ja czytałem pierwsze wersje artykułów, ujednoliciłem styl, starałem się usuwać zbyt wyszukane wyrażenia. Simei akceptował: Proszę państwa, uprawiamy tu dziennikarstwo, nie literaturę". U. Eco, Temat na..., s. 79.

${ }^{99} \mathrm{~W}$ okresie popularyzacji Nowego Dziennikarstwa w anglojęzycznym dyskursie naukowym wykształciła się nazwa gatunkowa „powieść dziennikarska”, definiowana jako dokumentarno-socjologiczny utwór o walorach aktualnościowych. Forma pełniąca również funkcję interwencyjną, charakteryzująca się szybką, choć powierzchowną reakcją (nadając uproszczony styl) na istotne wydarzenia współczesne. Nierzadko nazywana też „powieścią współczesną”, bowiem może stanowić przetworzenie dokumentu dziennikarskiego, na przykład newsa w powieść - literackie opracowanie faktów. Współcześnie określenia „powieść dziennikarska” używa się również w odniesieniu do reportaży zabarwionych elementem kreacji. Tak szerokie rozumienie gatunku sprawia, że w jego zakresie znajduje się zarówno „powieść faktu”, jak i zbeletryzowany „reportaż literacki”, odmiana „literackiego dziennikarstwa” - literary journalism. W Polsce jednak gatunek ten nie zdobył jeszcze popularności. I. Adamczewska, Powieść dziennikarska, „Zagadnienia Rodzajów Literackich", 2012, t. 55, z.1, s. 231-243. 
karstwa (przykładem autora łączącego wysokich lotów poezję i publicystykę byłby na przykład Czesław Miłosz z wierszami powstałymi po II wojnie światowej, w latach pięćdziesiątych). Praca pisarza jest w pewnym stopniu służbą społeczną, utwory w swojej idealnej postaci powinny realizować funkcję estetyczną oraz dydaktyczną. Do tego niezbędne są kwalifikacje intelektualne oraz moralne, dlatego tak ważna jest świadomość i umiejętność doboru właściwej tematyki i stylu w komunikatach trafiających do sfery publicznej. Aby zagwarantować wysoką jakość, można postulować, idąc za starożytnymi, demokratycznymi, wzorcami, rozdział sfery publicznej od tego, co winno pozostać w sferze prywatnej. Literatura w tym kontekście i ramie semiotycznej ma prawo do większej swobody, posiada licentia poetica, nie posiada jej natomiast dziennikarstwo. Osiągnięcie celu w obu sytuacjach zależy od kulturowej wiedzy autora oraz opanowania pisarskiego kunsztu. Z rozważań naszych wynika, że aby zachować standardy jakości w dziennikarstwie, domeny publiczna i prywatna powinny zachować stabilną równowagę, a społeczeństwo jako dobrowolne stowarzyszenie odpowiedzialnych jednostek powinno stanowić mechanizmy monitorowania tej równowagi. Otwarte pozostaje pytanie, jakimi mechanizmami - poza ekonomicznym - społeczeństwo powinno się posłużyć, aby tę równowagę zapewnić. Problemem staje się przypadek społeczeństw podlegających politykom niedemokratycznym. Ale to już zupełnie inny temat. 


\section{BIBLIOGRAFIA}

Adamczewska I., Gonzo journalism, „Zagadnienia Rodzajów Literackich” 2014, t. 57, z. 1. Adamczewska I., Powieść dziennikarska, „Zagadnienia Rodzajów Literackich” 2012, t. 55, Z. 1 .

Bajka Z., Dziennikarze lat dziewięćdziesiątych, „Zeszyty Prasoznawcze” 2000, nr 3-4.

Bauer Z., Chudziński E., Dziennikarstwo i świat mediów, Kraków 2000.

Chyliński M., Russ-Mohl S., Dziennikarstwo, Warszawa 2008.

Dziki S., Prasa w rozwoju historycznym, [w: ] Dziennikarstwo i świat mediów, red. Z. Bauer, E. Chudziński, Kraków 2000.

Eco U., Temat na pierwsza stronę, przeł. K. Żaboklicki, Warszawa 2015.

Fras J., Dziennikarski warsztat językowy, Wrocław 1999.

Habermas J., Strukturalne przeobrażenia sfery publicznej, przeł. W. Lipnik, M. Łukasiewicz, Warszawa 2007.

Hanczakowski M., Kuziak K., Zawadzki A., Żynis B., Epoki literackie. Od antyku do wspótczesności, Bielsko-Biała 2002.

Horacy, List do Pizonów, [w:] Trzy poetyki klasyczne: Arystoteles, Horacy, Pseudo-Longinos, przeł. i wstęp T. Sinko, Kraków 1951.

Kaszyński S. H., Opowieści wiedeńskiej kawiarni, Poznań 2004.

Kopaliński W., Opowieści o rzeczach powszednich, Warszawa 2007.

Kopaliński W., Stownik mitów i tradycji kultury, Warszawa 1985.

Lippmann W., Public Opinion, New York 1922.

McCombs M., Ustanawianie agendy. Media masowe i opinia publiczna, przeł. B. Radwan, Kraków 2009.

Piekot T., Dyskurs polskich wiadomości prasowych, Kraków 2006.

Pinker S., Piękny styl. Przewodnik człowieka myślącego po sztuce pisania XXI wieku, przeł. A. Nowak-Młynikowska, Sopot 2015.

Pinker S., The Sense of Style: The Thinking Person's Guide to Writing in the $21^{\text {st }}$ Century, London 2014.

Płuciennik J., Literatura, głupcze! Laboratoria nowoczesnej kultury literackiej, Kraków 2009.

Płuciennik J., Retoryka wzniosłości w dziele literackim, Kraków 2000.

Sinko Z., „Monitor” wobec angielskiego „Spectatora”, Wrocław 1956.

Skwarczyńska S., Teoria listu, oprac. E. Felisiak, M. Leś, Białystok 2006.

Turner M., Francis-Noël T., Clear and Simple As the Truth: Writing Classic Prose, Princeton 2011.

Wojtak M., Gatunki prasowe, Lublin 2004.

http: //pl.pons.com/t\%C5\%82umaczenie?q=colonna\&l=itpl\&in=\&lf=it [dostęp: 20.11.2015]. 